\title{
PENERAPAN KEGIATAN MERONCE BERBAHAN ALAM UNTUK MENINGKATKAN MOTORIK HALUS PADA ANAK USIA 5-6 TAHUN
}

\author{
Hatia Gay1, Bahran Taib², Haryati ${ }^{3}$ \\ Universitas Khairun Ternate \\ Fakultas Keguruan dan Ilmu Pendidikan \\ Jl. Bandarah Sultan Baabullah Kota Ternate Utara, Kotak Pos 53 Ternate 977328 \\ Telepon: (0921) 3110905-Faksimili 0921-3110901
}

Email: thiagay8@gmail.com¹, taibbahar4685@gmail.com²,haryati.mansur@gmail.com³

\begin{abstract}
Abstrak: Metode artikel ilmiah ini adalah library research atau kajian literatur. Penelitian literature yaitu penelitian yang tidak turun langsun kelapangan untuk bertemu dengan objek tetapi penelitian literatur ini di peroleh dari sumber internet yaitu jurnal atau artikel yang sudah dipublikasikan. Perkembangan motorik merupakan kesempatan yang luas untuk bergerak, pengalaman belajar untuk menemukan, aktivitas sensori motor yang meliputi penggunaan otot-otot besar dan kecil. Anak pada usia 5-6 tahun seharusnya anak sudah mampu mengambil benda dengan jari, memindahkan benda dari satu ke tangan yang lain dan sudah bisa memasukkan dan mengeluarkan benda. Salah satu aspek yang sangat penting dan perlu dikembangkan dalam proses pembelajaran anak usia dini adalah kemampuan fisik motorik halus. Dengan Kegiatan meronce dapat mendorong anak mengembangkan daya cipta yang ada di dalam dirinya anak, meronce menggunkan bahan alam merupakan salah satu upaya yang dapat diterapkan untuk meningkatkan motorik halus anak oleh karena itu motorik halus sangat penting bagi anak usia dini.
\end{abstract}

Kata Kunci : Kegiatan Meronce, Berbahan Alam, Motorik Halus.

Abstract: The method article scientific is library research or study literature. Literature research is not a type of field research to meet with the object but this literature research was obtained from internet media, namely journals or published articles. Motor development is a broad opportunity to move, learning experiences to discover, sensory activities which include the use of large and small muscles. Children at 5-6 years old should have been able to pick up object with their fingers and move the object from one to the other hand and can insert and remove objects. One aspect is very important and needs to be developed in the process of early childhood is fine motor ability. Threading can encourage children to develop the creativity that is in themselves, threading using natural materials applied to improve motor skills is very important for early childhood.

Key word: Threading , Natural materials, Fine Motor 


\section{A. PENDAHULUAN}

Pendidikam amak usia dini yang berada pada jalur formal, dimana pada usia ini merupakan masa keemasan khususnya usia $5-6$ tahun adalah masa terjadi pematangan fungsi - fungsi fisik dan psikis yang siap merespon stimulasi yang diberikan oleh lingkungan. Untuk mengembangkan beberapa aspek perkembangan, maka dibutuhkan suatu lembaga pendidikan yang tepat yaitu Pendidikan Anak Usia Dini. Pendidikan anak usia dini adalah suatu upaya pembinaan yang ditujukan kepada anak sejak lahir sampai dengan usia enam tahun yang dilakukan melalui pemberian rangsangan pendidikan untuk membantu pertumbuhan dan perkembangan jasmani. Anak merupakan salah satu bentuk penyelenggaraan pendidikan yang menitik beratkan pada peletakan dasar kearah pertumbuhan dan perkembangan fisik, kecerdasan, sosial emosional, bahasa, sesuai dengan keunikan dan tahap - tahap perkembangan yang dilalui oleh anak usia dini.

Undang-undang Nomor 20 Tahun 2003 tentang Sistem Pendidikan Nasional Pasal 1 angka 14 menyatakan bahwa Pendidikan Anak Usia Dini (PAUD) adalah suatu upaya pembinaan yang ditujukan kepada anak sejak lahir sampai usia enam tahun yang dilakukan melalui pemberian rangsangan pendidikan untuk membantu pertumbuhan dan perkemangan jasmani dan rohani agar anak memiliki kesiapan dalam memasuki pendidikan lebih lanjut. Pendidikan anak usia dini diharapkan menjadi bekal dan kesiapan dalam memasuki pendidikan yang lebih selanjutnya.

Pendidikan anak usia dini merupakan salah satu bentuk pendidikan dasar bagi anak usia dini melalui beberpa tahap yaitu: 1. Pertumbuhan dan perkembangan fisik yaitu motorik kasar dan halus ,2. Kecerdasan yaitu daya pikir, daya cipta, kecerdasan emosi, kecerdasan spiritual. 3. Sosial emosional yaitu sikap dan perilaku serta agama, bahasa, dan komunikasi yang disesuaikan dengan keunikan dan tahap-tahap perkembangan yang dilalui oleh anak usia dini.

Pendidikan anak usia dini adalah suatu upaya pembinaan yang ditujukan kepada anak sejak lahir sampai usia enam tahun yang dilakukan melalui pemberian rangsangan pendidikan untuk membantu pertumbuhan dan perkembangan jasmani dan rohani agar anak memiliki kesiapan dalam memasuki pendidikan lebih lanjut. Salah satu aspek yang sangat penting dan perlu dikembangkan dalam proses pembelajaran anak usia dini adalah kemampuan fisik motorik halus.

Kegiatan meronce dengan tujuan agar dapat mendorong anak mengembangkan daya cipta yang ada di dalam dirinya anak. Maka dari itu kegiatan meronce dengan bahan alam sangat bermanfaat bagi anak, meronce dengan bahan alam dapat meningkatkan nilai agama dan moral bagi anak. Meronce menggunkan bahan alam merupakan salah satu upaya yang dapat diterapkan untuk meningkatkan motorik halus anak. Anak dapat belajar kreatif, keterampilan tangan ketelitian, kerapian dan koordinasi pusat-pusat syaraf, otot, mata dan tangan pada anak. Kegiatan meronce anak mampu melatih kemampuan motorik halus anak melalui pemahaman $\mathrm{t}$ erhadap warna, pola dan mengurutkan benda berdasarkan ukuran yang dirangkain. Meronce $\mathrm{m}$ enggunakan bahan alam merupakan sumber belajaryang tak terbatas bagi anak untuk berekspo larasi dan berinteraksi sesama teman dan mampu membangun pengetahuan dan pemahaman yang baru bagi anak..

Perkembangan motorik merupakan kesempatan yang luas untuk bergerak, pengalaman belajar untuk menemukan, aktivitas sensori motor yang meliputi penggunaan otot-otot besar 
dan kecil memungkinkan anak untuk memenuhi perkembangan motorik halus. Pada dasarnya perkembangan motorik pada anak meliputi motorik kasar dan motorik halus. Perkembangan motorik tentunya berkaitan dengan otot-otot yang ada di badan. Otot-otot badan tersebut merupakan gerakan tubuh yang menggunakan otot-otot besar atau sebagian besar atau seluruh anggota tubuh yang dipengaruhi oleh kematangan anak itu sendiri. Fungsi dari otot-otot tersebut adalah untuk melakukan gerakan dasar tubuh yang terkoordinasi oleh otak seperti berjalan, berlari, melompat, menendang dan sebagainya.

Otot-otot kecil berfungsi untuk melakukan gerakan-gerakan bagian tubuh yang lebih spesifik, seperti menulis, melipat, menggunting, meronce. Anak pada usia 5-6 tahun seharusnya anak sudah mampu mengambil benda dengan jari, memindahkan benda dari satu ke tangan yang lain dan sudah bisa memasukkan dan mengeluarkan benda. Melihat dari tahapan kemampuan motorik halus tersebut ada salah satu kegiatan yang dapat mengembangkan kemampuan motorik halus yaitu meronce. Meronce merupakan cara pembuatan benda hias atau benda pakai yang dilakukan dengan menyusun bagian-bagian bahan berlubang atau sudah dilubangi memakai bantuan lidi dan benang. Kedua kemampuan tersebut sangat penting agar anak bisa berkembang dengan optimal dan dapat mengerjakan tugas-tugas dengan lancar.

Peningkatan keterampilan motorik halus anak sanggat berdampak positif pada aspek perkembangan yang lain pula. Kemampuan motorik halus adalah salah satu kemampuan dan potensi yang terdapat pada setiap anak yang memerlukan dasar-dasar keterampilan melalui latihan dan pembinaan. Salah satu stimulus yang dapt digunakan untuk meningkatkan kemampuan motorik halus anak adalah kegiatan meronce. Dimana kegiatan ini merupakan kegiatan menggerakkan jari-jarinya, mengenal warna, koordinasi tangan dan mata yang sudah baik maka anak sudah dapat melakukan kegiatan motorik halus seperti menulis, melipat, menggunting, menjepit, melukis dan sebagainya.

Oleh karena itu untuk mengoptimalkan pertumbuhan dan perkembangan anak dalam meningkatkan kemampuan motorik halus perlu adanya pendekatan baik dari orang tua dan guru. Kegiatan meronce merupakan suatu seni dan pembelajaran yang dapat meningkatkan keterampilan motorik halus anak yaitu pendekatan seni yang dapat dijadikan materi dalam pembelajaran bagi anak usia dini yaitu kegiatan meronce.

\section{B. KAJIAN TEORI}

\section{Kegiatan Meronce Berbahan Alam}

Salah satu kegiatan yang dapat meningkatkan motorik halus yaitu meronce, meronce merupakan tindakan atau kegiatan untuk dapat merangkai benda menjadi kesatuan. Menurut (Rukmono dalam Tiara 2015), meronce adalah suatu teknik membuat hiasan yang siap pakai dari bahan manik-manik, biji-bijian, dan bahan-bahan lainnya, yaitu dengan cara merangkainya dengan benang atau senar. Kegiatan meronce adalah menata dengan bantuan mengikat komponen utas atau tali. Meronce merupakan pekerjaan yang mencerminkan wujud penghargaan terhadap keindahan benda-benda alam.

(Hajar, dkk dalam Rosidah 2018) meronce adalah teknik membuat benda pakai/hias dari bahan manik-manik, biji-bijian atau bahan lain yang dapat dilubangi dengan alat tusuk sehingga dapat dipakai. Kegiatan meronce adalah salah satu materi yang bisa diberikan pada anak usia dini. Kegiatan meronce untuk meningkatkan kemampuan motorik 
halus anak usia dini juga telah didukung oleh penelitian sebelumnya yang diketahui bahwa kegiatan meronce dapat meningkatkan kreativitas anak berdasarkan penelitian yang dilakukan oleh (Widiastini, dkk, dalam Krisna, dkk 2018).

Adapun manfaat meronce merupakan kagiatan yang menyenangkan untuk anak, menurut (Sumanto, dalam Ari Wulandari1 2019) bahwa "meronce merupakan cara pembuatan benda hias atau benda pakai yang dilakukan dengan menyusun bagian-bagian bahan berlubang atau yang sengaja dilubangi memakai bantuan benang, tali dan sejenisnya". Menurut (Sumantri, dalam Ari Wulandari 2019) meronce adalah "salah satu kegiatan pengembangan motorik halus di TK, kegiatan menguntai dengan membuat untaian dari bahan-bahan yang berlubang, disatukan dengan tali atau benang".

Menurut (Yani Mulyani, dkk dalam Handayani Tri Rezeki 2016) yaitu: melatih konsentrasi anak, merangsang kreativitas anak, melatih koordinasi mata dan jari tangan anak, dan mengenal konsep warna dan keserasian anak.

Menurut (Hajar Pamadhi, dkk dalam Handayani Tri Rezeki 2016) yaitu:

a. Permainan merangkai maupun meronce berfungsi sebagai alat bermain anak, bendabenda yang akan dirangkai tidak ditujukan untuk kebutuhan tertentu melainkan untuk latihan memperoleh kepuasan rasa dan memahami keindahan.

b. Bahan atau inovasi. Merangkai dan meronce dapat ditujukan untuk melatih kreativitas, yaitu dengan cara mengubah fungsi lama menjadi fungsi baru.

Berdasarkan uraian diatas dapat diambil kesimpulan bahwa meronce dapat membantu kemampuan motorik halus, melatih koordinasi mata dan tangan, serta meningkatlan perhatian dan konsentrasi sehingga dengan kegiatan meronce anak akan merasakan dan mendapatkan pengalaman langsung serta terampil untuk melakukan kegiatan yang menggunkan kemampuan motorik halus dan lainnya.

Menurut ( Pamadhi dalam Nur Baiti 2018 ), beberapa aspek meronce yaitu:

a. Permainan Merangkai maupun meronce dapat berfungsi untuk alat bermain anak.

b. Kreasi dan Komposisi Meronce sengaja hanya digunakan untuk bermain imajinasi saja.

c. Keindahan Aspek keindahan dari meronce terletak pada cara menyusun benda-benda sebagai komponen rangkaian untuk menarik perhatian.

d. Kerajinan dan ketekunan menuntut ketelitian yaitu usaha memberikan pelatihan menyusun, menata dalam bentuk rangkaian yang sesuai dengan rancangan dan tidak mudah rusak susunannya.

Bahan alam adalah bahan yang dapat diperoleh dari lingkungan alam sekitar yaitu bunga segar, buah buahan, bunga kering, daun kering, ranting dan biji-bijian (Ropiah 2019). Meronce dengan bahan alam sangat efektif dalam kegiatan pembelajaran dapat meningkatkan motorik halus kemampuan motorik halus anak, dengan kegiatan meronce dengan bahan alam anak dapat menyusun pola- pola sesuai dengan warna. (Syafi'I, dalam Niamul 2018) menyatakan bahwa, bahan alam adalah bahanbahan yang bersumber dari alam baik itu tumbuhan-tumbuhan yang hidup di alam. Dengan demikian menjadi alternatif baru sebagai salah satu kegiatan pembelajaran dengan menggunakan bahan dari alam yang murah, mudah di dapat, tidak menggunakan biaya terlalu mahal dan yang pasti aman untuk anak usia dini. 
Berdasarkan beberapa teori di atas dapat diambil kesimpulan bahwa kegiatan meronce menggunakan bahan alam sangat bermanfaat untuk anak usia 5-6 tahun, dengan kegiatan meronce anak dapat meningkatkan motorik halus melalui koordinasi mata, tangan serta anak dapat meningkatkan perhatian dan konesntrasi anak dalam membuat kegiatan meronce, dan juga anak dapat menciptkan suatu karya atau pengalaman yang baru.

\section{Perkembangan Motorik Halus}

Perkembangan motorik anak terbagi menjadi dua bagian, yaitu gerakan motorik kasar dan gerakan motorik halus. Gerakan motorik kasar adalah kemampuan yang membutuhkan koordinasi sebagian besar bagian tubuh anak. Seperti meloncat, memanjat, berlari, menaiki sepeda, berdiri dengan satu kaki dan sebagainya. Gerakan motorik halus adalah bila gerakan hanya melibatkan bagian-bagin tubuh tertentu saja dan dilakukan oleh otot-otot kecil, seperti keterampilan menggunakan jari jemari tangan dan gerakan pergelangan tangan yang tepat gerakan ini membutuhkan koordinasi mata dan tangan. Gerakan motorik halus yang terlihat pada anak usia dini, antara lain adalah anak mulai dapat menyikat giginya, menyisir, memakai sepatu sendiri, menggunting dan sebagainya.

(Sumantri dalam Ropiah 2019), menyatakan bahwa motorik halus adalah pengorganisasian penggunaan sekelompok otot-otot kecil seperti jari-jemari dan tangan yang sering membutuhkan kecermatan dan koordinasi dengan tangan, keterampilan yang mencakup pemanfaatan menggunakan alat-alat untuk mengerjakan suatu objek. Demikian pula menurut (Sujiono dalam Ropiah 2019) menyatakan bahwa motorik halus adalah gerakan yang hanya melibatkan bagian-bagian tubuh tertentu saja dan dilakukan oleh otototot kecil, seperti keterampilan menggunakan jari jemari tangan dan gerakkan pergelangan tangan yang tepat. Oleh karena itu, gerakkan ini tidak terlalu membutuhkan tenaga, namun gerakan ini membutuhkan koordinasi mata dan tangan yang cermat. Semakin baiknya gerakan motorik halus anak membuat anak dapat berkreasi, seperti meronce. Namun tidak semua anak memiliki kematangan untuk menguasai kemampuan ini pada tahap yang sama. Perkembangan motorik merupakan salah satu faktor yang sangat penting dalam perkembangan individu secara keseluruhan.

Beberapa pengaruh perkembangan motorik terhadap konstrasi perkembangan individu menurut (Hurlock dalam Ropiah 2019) adalah sebagai berikut:

a. Melalui keterampilan motorik, anak dapat menghibur dirinya dan memperoleh perasaan senang. Seperti anak merasa senang dengan memiliki keterampilan memainkan boneka, melempar dan menangkap bola atau memainkan alat-alat mainan.

b. Melalui keterampilan motorik, anak dapat beranjak dari kondisi tidak berdaya pada bulan-bulan pertama dalam kehidupannya, ke kondisi yang independen. Anak dapat bergerak dari satu tempat ke tempat lainnya dan dapat berbuat sendiri untuk dirinya. Kondisi ini akan menunjang perkembangan rasa percaya diri.

c. Melalui perkembangan motorik, anak dapat menyesuaikan dirinya dengan lingkungan sekolah. Pada usia prasekolah atau usia kelas-kelas awal Sekolah Dasar, anak sudah dapat dilatih menulis, menggambar, melukis, dan baris berbaris.

d. Melalui perkembangan motorik yang normal memungkinkan anak dapat bermain atau bergaul dengan teman sebayannya, sedangkan yang tidak normal akan menghambat anak untuk dapat bergaul dengan teman sebayanya bahkan dia akan terkucilkankan atau menjadi anak yang fringer (terpinggirkan). 
Dalam melakukan gerakan motorik halus anak juga memerlukan dukungan keterampilan fisik serta kematangan mental (Sujiono, dalam Mansyur 2017). Perkambangan motorik halus adalah pengorganisasian penggunaan sekelompok otot-otot kecil seperti jari jemari dan tangan yang sering membutuhkan kecermatan dan koordinasi dengan tangan. (Sumantri, dalam Gusti Ayu 2019) menyatakan hal yang sama dikemukakan dalam (soejono 2019) bahwa motorik halus adalah gerakan yang melibatkan bagian-bagian tubuh tertentu dan dilakukan oleh otot-otot kecil (halus) serta memerlukan koordinasi yang cermat seperti menggunting, mengikuti garis, menulis, meremas, menggenggam menggambar, menyusun balok, memasukkan kelereng ke lubang, membuka dan menutup objek dengan mudah, menuangkan air kedalam gelas tanpa berceceran, menggunakan kuas, krayon dan spidol serta melipat.

(Magill Richard ,dalam Andri Setia Ningsih 2015) mengatakan bahwa keterampilan motorik halus (fine motor skill) merupakan keterampilan yang memerlukan kontrol dari otot-otot kecil dari tubuh untuk mencapai tujuan dari keterampilan. Menurtu (Mahendra,dkk dalam Effi kumala sari 2012:3) menjelaskan keterampilan motorik halus merupakan keterampilan-keterampilan yang memerlukan untuk mengontrol otot-otot kecil/halus untuk mencapai pelaksanaan keterampilan yang berhasil. (Gallahue dkk, dalam Selia Dwi Kurnia 2015) keterampilan motorik halus gerakan terbatas dari bagian tubuh dalam hal ketepatan ketelitian dan gerak manipulasi. (Santrock, dalam setia Dwi Kurnia 2015) keterampilan motorik halus merupkan keterampilan motorik yang melibatkan gerakan yang lebih diatur secara halus seperti keterampilan tangan.

Motorik halus di usia 5-6 tahun bertujuan supaya anak mampu mengembangkan kemampuan motorik halus yang berhubungan dengan keterampilan gerak kedua tangan. Anak mampu menggerakan yang berhubungan dengan jari jemari seperti kesiapan menulis, menggambar dan memanipulasi benda-benda. Secara khusus tujuan pengembangan motorik halus untuk anak usia TK (5-6 tahun) adalah anak dapat menunjukan kemampuan mengerakkan anggota tubuhnya dan terutama terjadinya koordinasi mata dan tangan sebagai persiapan untuk pengenalan menulis (Puskar, Balitbang Depdiknas:19 2002).

(Sumantri 2005) menjelaskan bahwa tujuan pengembangan motorik halus di usia 4-6 tahun yaitu:

a. Mampu mengembangkan kemampuan motorik halus yang berhubungan dengan keterampilan gerak kedua tangan.

b. Mampu mengkoordinasikan indra mata dan aktivitas tangan.

c. Mampu mengerakkan anggota tubuh yang berhubungan dengan gerak jari jemari seperti kesiapan menulis, menggambar dan memanipulasi benda-benda.

d. Mampu mengendalikan emosi dengan beraktivitas motorik halus.

Tujuan motorik halus adalah mengkaji proses pertahapan kemampuan gerak, apakah kemampuan gerak individu tersebut sudah sesuai dengan tahapan usianya sehingga pendidik bisa mendesain pembelajaran seperti apa yang tepat digunakan dalam meningkatkan motorik halus anak. (Saputra, dkk dalam Fida 2017) memaparkan tujuan pengembangan motorik halus anak yaitu: Mampu memfungsikan otot-otot kecil seperti gerakan jari tangan. Gerakan ini keterampilan bergerak, yang bisa mencakup beberapa fungsi yaitu Mampu mengkoordinasikan kecepatan tangan dengan mata. 
(Sujiono, dalam Fida 2017) dalam buku yang berjudul Metode Pengembangan Fisik menyatakan bahwa tujuan dari pembelajaran motorik halus anak usia dini yaitu:

a. Diharapkan anak mampu melakukan aktivitas fisik secara terkoordinasi dalam rangka kelenturan dan persiapan menulis, keseimbangan, kelincahan, dan melatih keberanian.

b. Anak bisa mengekspresikan diri dan berkreasi dengan berbagai gagasan dan imajinasi serta menggunakan berbagai media menjadi suatu karya seni.

(Saputra, dkk dalam Fida 2017) menyebutkan manfaat dari keterampilan motorik halus yaitu sebagai alat untuk mengembangkan keterampilan gerak kedua tangan dan mengembangkan koordinasi kecepatan tangan dengan gerakan mata. (Mutahir, dalam Fida 2017) juga menjelaskan bahwa manfaat utama motorik ialah mengembangkan kesanggupan dari keterampilan setiap individu yang berguna untuk mempertinggi daya kerja.

Melatih kelenturan otot jari tangan Dirjen Manajemen Pendidikan Sekolah Dasar dan Menengah, (dalam Fida 2017) memaparkan manfaat keterampilan motorik halus adalah sebagai berikut:

a. Memacu pertumbuhan dan perkembangan motorik halus dan rohani

b. Meningkatkan perkembangan emosi anak

c. Menumbuhkan perasaan menyenangi terhadap diri sendiri

Pendapat yang dipaparkan oleh para ahli tentang manfaat motorik halus anak dapat ditarik kesimpulan bahwa secara singkat manfaat dari keterampilan motorik halus adalah sebagai pendukung aspek perkembangan yang lainnya karena aspek satu dengan lainnya saling berkaitan, selain juga menjadikan anak lebih terampil dalam mengkoordinasikan gerakan halus mereka serta melatih emosi ketika anak merasa senang melakukan gerakan dalam kegiatan motorik halus tersebut.

Fungsi perkembangan motorik halus Menurut (Mudjito dalam Fida2017) mencatat beberapa alasan tentang fungsi perkembangan motorik halus yaitu: Melalui keterampilan motorik, anak dapat menghibur dirinya dan memperoleh perasaan senang. Melalui keterampilan motorik, anak dapat menyesuaikan dirinya dengan lingkungan sekolah.

Pengorganisasian penggunaan sekelompok otot-otot kecil seperti jari-jemari dan tangan yang sering membutuhkan kecermatan dan koordinasi mata dengan tangan . Otototot tersebut berfungsi untuk melakukan gerakan-gerakan bagian tubuh yang lebih spesifik, seperti menulis, melipat, menggunting, meronce (Ropiah 2019).

Berdasarkan beberapa pendapat teori di atas dapat disimpulkan bahwa tujuan peningkatan motorik halus yaitu untuk meningkatkan kemampuan agar anak dapat mengembangkan motorik halusnya melalui jari tangan dan koordinasi mata yang lebih optimal lagi serta sebagai kegiatan meronce untuk mengekspresikan emosi dan potensi diri dalam berbagai kegiatan yang memerlukan otot halus. 


\section{METODE PENELITIAN}

Metode artikel ilmiah ini adalah library research atau kajian literatur. Penelitian literatur yaitu penelitian yang tidak turun langsung ke lapangan untuk bertemu dengan objek tetapi penelitian literatur ini di peroleh dari sumber internet yaitu jurnal atau artikel yang sudah dipublikasikan.

Sedangkan menurut (Zeed Mestika, dalam Reisa 2020) menyatakan bahwa metode penelitian dengan pendekatan studi literatur merupakan penelitian yang serangkain kegiatannya dengan metode pengumpulan data pustaka, buku-buku, serta tulisan yang terkait dengan judul penelitian ini dari perpustakaan kamus online.

\section{HASIL DAN PEMBAHASAN}

\section{Hasil}

Berdasarkan hasil yang di dapat dari beberapa pepenelitian sebelumnya terkait penerpan kegiatan meronce berbahan alam untuk meningkatkan motorik halus pada anak usia 5-6 tahun yang dikemuka oleh beberapa peneilitian sebagi berikut.

Penelitian dilakukan oleh (Anik Tri Rahayu 2016) dengan hasil pengamatan dan pengalaman peneliti, bahwa pembelajaran motorik halus di TK PKK Selodono masih kurang berkembang. Hal ini disebabkan oleh metode pembelajaran yang digunakan masih menggunakan metode tanya jawab dan bercakap-cakap. Akibatnya suasana kelas monoton dan membosankan. Untuk itu perlu adanya perubahan ke arah yang lebih baik yaitu melalui kegiatan meronce. Permasalahan yang akan dipecahkan dalam penelitian ini adalah "apakah kegiatan meronce bahan alam dapat meningkatkan kemampuan motorik halus anak pada kelompok B TK PKK Selodono tahun pelajaran 2015/2016?" Subjek Penelitian adalah anak kelompok B dengan jumlah anak didik sebanyak 26 anak, dengan rincian anak sebagai subjek penelitian karena pada kelompok B kemampuan motorik halus masih rendah, ini dapat dibuktikan dengan adanya penilaian dari 26 anak hanya ada 11 anak yang mendapatkan nilai MB dan 15 anak mendapatkan nilai BB. Selain itu peneliti bertugas di tempat ini sehingga sangat membantu mempermudah kelancaran pelaksanaan penelitian. Penelitian ini menggunakan pendekatan, penelitian Tindakan Kelas (PTK). Penelitian ini dilakukan dalam tiga siklus yaitu, siklus I, siklus II, dan siklus III yang terdiri dari empat tahap yaitu perencanaan, pelaksanaan, observasi dan refleksi. Penelitian ini menggunakan instrumen berupa RPPM, RPPH, lembar penilaian anak didik, lembar observasi guru. Pada siklus I terdapat hasil yang menyatakan bahwa sebanyak $27 \%$ dari 26 anak memenuhi kriteriaketuntasan dengan mendapat nilai BSH dan BSB, sedangkan pada siklus II hasilnya meningkat menjadi 58\%, dan pada siklus III sebanyak $88 \%$

Penelitian dilakukan oleh (Ari Wulandari, Dkk 2019). Penelitian ini adalah penelitian tindakan kelas yang bertujuan untuk mengetahui peningkatkan perkembangan motorik halus melalui penerapan metode demonstrasi melalui kegiatan meronce. Penelitian tindakan kelas ini menggunakan 2 siklus. Subjek penelitian ini adalah anak kelompok B1 TK Kartika Singaraja yang berjumlah 19 orang. Instrument penelitian ini menggunakan lembar observasi. Data hasil penelitian dianalisis menggunakan metode analisis statistik deskriptif dan metode analisis deskriptif kuantitatif. Hasil analisis data menunjukkan bahwa terjadi peningkatan perkembangan motorik halus dari penerapan metode demonstrasi melalui 
kegiatan meronce mencapai $22,43 \%$. Pada siklus I sebesar $59,58 \%$ yang berada pada kriteria rendah mengalami peningkatan pada siklus II menjadi $82,01 \%$ tergolong kriteria tinggi. Dengan demikian dapat disimpulkan bahwa penerapan metode demonstrasi melalui kegiatan meronce dapat meningkatkan perkembangan motorik halus pada anak kelompok B1 TK Kartika VII-3 Singaraja.

(Nur Rohmah, 2014) Metode penelitian yang digunakan dalam penelitian menggunakan penelitian tindakan kelas dengan 3 siklus yang masing-masing siklus dilaksanakan 3 kali pertemuan. Setiap pertemuan ada 4 langkah kegiatan yaitu perencanaan, pelaksanaan, observasi dan refleksi. Hasil dari penelitian dapat disimpulkan bahwa pembelajaran motorik halus dengan meronce menggunakan media alam dapat memotivasi dan meningkatkan hasil belajar anak di Kelompok B TK Pertiwi 2 Plumbon Kabupaten Sragen. Hal ini dapat dilihatdalam Prasiklus, hasil yang dicapai anak yang Anak mampu mengerjakan sendiri tanpa bantuan guru (Tuntas) 8\%, sedang yang Anak mampu mengerjakan sendiri dengan sedikit bantuan guru (Cukup) 12\%, Anak dalam mengerjakan selalu meminta bantuan guru / anak yang tidak mau mengerjakan tugas (Belum Tuntas) $80 \%$. Siklus I dengan hasil yang dicapai anak yang Anak mampu mengerjakan sendiri tanpa bantuan guru (Tuntas) 16\%, sedang anak yang Anak mampu mengerjakan sendiri dengan sedikit bantuan guru (Cukup) 36\%, Anak dalam mengerjakan selalu meminta bantuan guru / anak yang tidak mau mengerjakan tugas (Belum Tuntas) 48\%. Dalam siklus II peneliti menggunakan bahan alam berupa pelepah daun singkong, hasilnya dapat dilihat bahwa kemampuan belajar anak yang meningkat secara signifikan hasil belajar anak dari siklus I terhadap siklus II, anak anak yang anak mampu mengerjakan sendiri tanpa bantuan guru (Tuntas) $80 \%$, sedang anak yang mampu mengerjakan sendiri dengan sedikit bantuan guru (Cukup) 8\%, Anak dalam mengerjakan selalu meminta bantuan guru / anak yang tidak mau mengerjakan tugas (Belum Tuntas) menjadi $12 \%$.

(Rosidah, 2018 ) Penelitian tindakan kelas dilaksanakan dua siklus yaitu siklus I dan siklus II. Tiap siklus masing-masing terdapat perencanaan, pelaksanaan, pengamatan dan refleksi. Adapun metode pengumpulan data yang digunakan meliputi observasi, tes, dan dokumentasi. Analisis data yang dilakukan dengan cara menghitung pencapaian nilai hasil belajar tiap siklus dengan ditandai peningkatan Kriteria Ketuntasan Klasikal. Temuan penelitian ini menunjukkan bahwa melalui kegiatan meronce dengan media tutup botol hias dapat mengembangkan fisik motorik halus di kelompok A BA Aisyiyah Repaking Kecamatan Wonosegoro Kabupaten Boyolali Tahun 2017/2018. Hal ini dapat dibuktikan dengan hasil penelitian sebagai berikut: Pra-siklus terdapat 17 siswa (56,66\%) yang tuntas dan 13 siswa $(43,33)$ yang belum tuntas dengan nilai rata-rata kelas 58,8. Meningkat pada Siklus I terdapat 23 siswa $(76,66 \%)$ yang tuntas dan 7 siswa $(23,33 \%)$ yang belum tuntas dengan nilai rata-rata kelas 69,7. Meningkat lagi pada Siklus II terdapat 29 siswa (96,66\%) yang sudah tuntas dan 1 siswa (3,33\%) yang belum tuntas dengan nilai-rata kelas 91 .

(Nur Baiti, 2018 ) Penelitian ini dilatar belakangi hasil pengamatan dan pengalaman peniliti di Kelompok TK Dharma Wanita 03 Padangan Ngantru Tulungagung tahun pelajaran 2017/ 2018. Bahwa dalam proses pembelajaran kemampuan fisik motorik halus yang masih dilaksanakan masih menggunakan metode yang kurang bervariatif. Pemanfaatan kegiatan pembelajaran yang menumbuhkan inovasi belajar anak kurang diterapkan dalam proses pembelajaran. Proses pembelajaran kemampuan fisik motorik halus anak masih dilaksanakan secara monoton dan kurang menarik minat anak, sehingga kemampuan fisik motorik halus anak menjadi rendah. Permasalahan yang akan dipecahkan 
dalam penelitian ini adalah apakah mengembangkan kemampuan motorik halus melalui kegiatan meronce bahan alam pada anak Kelompok A TK Dharma Wanita 03 Padangan Ngantru Tulungagung tahun pelajaran 2017/ 2018? Penelitian ini menggunakan pendekatan Penelitian Tindakan Kelas PTK). Subjek penelitian ini anak Kelompok A TK Dharma Wanita 03 Padangan Ngantru Tulungagung berjumlah 11 anak. Teknik analisis data dilakukan menggunakan pendekatan deskriptif kuantitatif. Instrument penilaian RPPM, $\mathrm{RPPH}$, lembar kemampuan motorik halus anak, lembar observasi kegiatan pembelajaran guru.

Penelitian yang dilakukan oleh (Ropia 2019 ) adalah melalui kegiatan meronce dapat meningkatkan kemampuan motorik halus anak usia dini TK Pembina 2 Kota Jambi di kelas B1. Kemampuan motorik halus yang ditingkatkan meliputi meronce menggunakan sisik ikan nila, kalender bekas dan benang. Selain itu kemampuan motorik halus dapat ditingkatkan dengan melaksanakan kegiatan yang menggunakan jari-jemari seperti mengambil benda dengan jari, memindahkan benda dari tangan yang satu ke tangan yang lain, memasukkan dan mengeluarkan benda dari wadah yaitu kegiatan mengambil bijibijian.

Berdasarkan hasil data yang diperoleh bahwa kemampuan motorik halus anak dalam dari observasi dan sesudah tindakan kelas mengalami perkembangan. Hal ini dapat diketahui dari hasil penilaian dimana rata-rata kemampuan motorik halus anak pada mengalami peningkatan menjadi 80\% dimana terdapat 13 anak dari jumlah 15 anak. Hal tersebut menunjukkan, bahwa tindakan yang dilakukan melalui kegiatan meronce mampu meningkatkan kemampuan motorik halus anak kelompok bermain anak didik usia dini kelas B1 di Tk Pembina 2 Kota Jambi usia 5-6 tahun.

Dari hasil penelitian sebelumnya yang dapat disimpulkan bahwa dengan kegiatan meronce bahan alam dapat meningkatkan kemampuan motorik halus pada anak usia dini, karena kegiatan meronce dapat memecahkan permasalah yang terjdi pada perkembangan motorik halus pada anak usia dini. Hal ini dapat dibuktikan dari data-data hasil penelitian sebelumnya.

\section{Pembahasan}

Meronce menggunakan bahan alam untuk meningkat motorik halus pada usia 5-6 tahun, bahan alam yang digunakan untuk meronce adalah kacang dan wortel sesuai dengan ide yang sudah di tentukan. Dengan bahan alam ini sangat bermanfaat untuk anak usia 5-6 tahun dengan kegiatan meronce anak bisa berimejinasi untuk menciptakan suatu karya yang baru, selain dari itu anak juga bisa mengatahui ciptan Allah yang ada di sekitar lingkungan anak. Dengan mengkombinasikan bahan yang digunakan yaitu kacang panjang dan wortel dan benang tersebut dapat meningkatkan kinerja anak yang mana dari bahan tersebut. Bahan-bahan ini juga mudah di dapatkan untuk melaksanakan kegiatan meronce.

Anak usia dini yaitu anak yang sedang pesat pertumbuhanya dan perkembanganya baik itu fisik atau psikis serta anak-anak yang berusia dibawah 5- 6 tahun. Jadi mulai dari anak lahir hingga ia mencapai umur 6 tahun ia akan dikategorikan sebagai anak usia dini. Menurut (Husein dkk dalam Sumantri 2005) anak usia dini berada pada masa lima tahun pertama yang disebut The Golden Age. Masa ini merupakan masa emas perkembangan anak (Sumantri, dalam Suriatu dkk 2020). Pada periode ini hampir seluruh potensi anak 
mengalami masa peka untuk tumbuh dan berkembang secara cepat. Apabila anak mendapatkan stimulus yang baik, maka seluruh aspek perkembangan anak akan berkembang secara optimal. Salah satu aspek yang penting untuk dikembangkan adalah aspek perkembangan motorik terutama motorik halus.

Motorik adalah semua gerakan yang mungkin dapat dilakukan oleh seluruh tubuh, sedangkan gerakan motorik dapat disebut sebagai perkembangan dari unsur kematangan dan pengendalian gerak tubuh. Perkembangan motorik ini erat kaitannya dengan pusat motorik di otak. Perkembangan motorik berkembang sejalan dengan kematangan syaraf dan otak. Oleh sebab itu, setiap gerakan yang dilakukan anak sederhana apapun, sebenarnya merupakan hasil pola interaksi yang kompleks dari berbagai dan sistem dalam tubuh yang dikontrol otak, otaklah yang berfungsi sebagai bagian dari susunan syaraf yang mengatur dan mengontrol semua aktivitas fisik dan mental seseorang. Aktivitas anak terjadi di bawah kontrol otak. Secara simultan dan berkesinambungan, otak terus mengolah informasi yang ia terima. Bersamaan dengan itu, otak bersama jaringan syaraf yang membentuk sistem syaraf pusat yang mencakup lima pusat kontrol, setiap gerak anak. Dalam kaitannya dengan perkembangan motorik ana $\mathrm{k}$, perkembangan motorik berhubungan dengan perkembangan kemampuan gerak anak. Gerak merupakan unsur utama dalam perkembangan motorik anak, oleh sebab itu, perkembangan kemampuan motorik anak akan dapat terlihat secara jelas melalui berbagai gerakan dan permainan yang mereka lakukan (Mansyur Romadon Putra 2017)

Alat dan bahan yang di gunakan yaitu: wortel, kacang panjang, benang dan lidi.

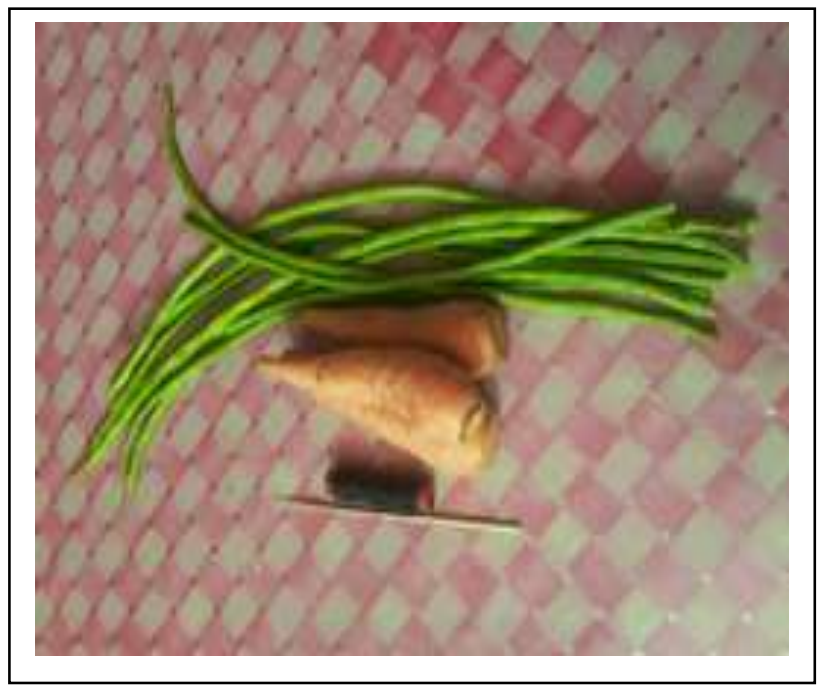

Gambar 1. Alat dan Bahan

Cara bermain sebagai berikut:

a. Siapkan potongan wortel dan kacang panjang,

b. Lubangkan wortel dan kacang panjang yang menggunakan lidi

c. Buatkan pola

d. Buatkan simpul benang 
e. Masukkan benang kedalam kacang panjang dan wortel yang sudah di lubang sesuian dengan pola

f. Membuat kalung, atau gelang dari kacang panjang dan wortel dan lain-lain.

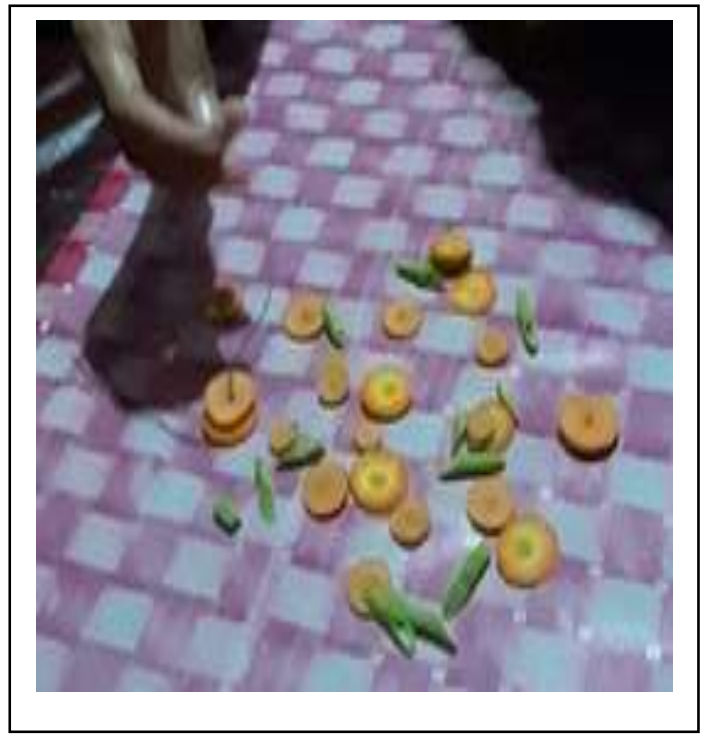

Gambar 2. Cara Bermain

Manfaat dari meronce yaitu:

a. Melatih motorik halus

b. Melatih konsentrasi pada anak

c. Melatih kesebaran pada anak

d. Melatih kreativitas pada anak

e. Menstimulasikan otak tangan anak kedalam tahap perkembangan menulis pada anak untuk memasuki jenjng selanjutnya

f. Melatih kordinasi mata dan tangan

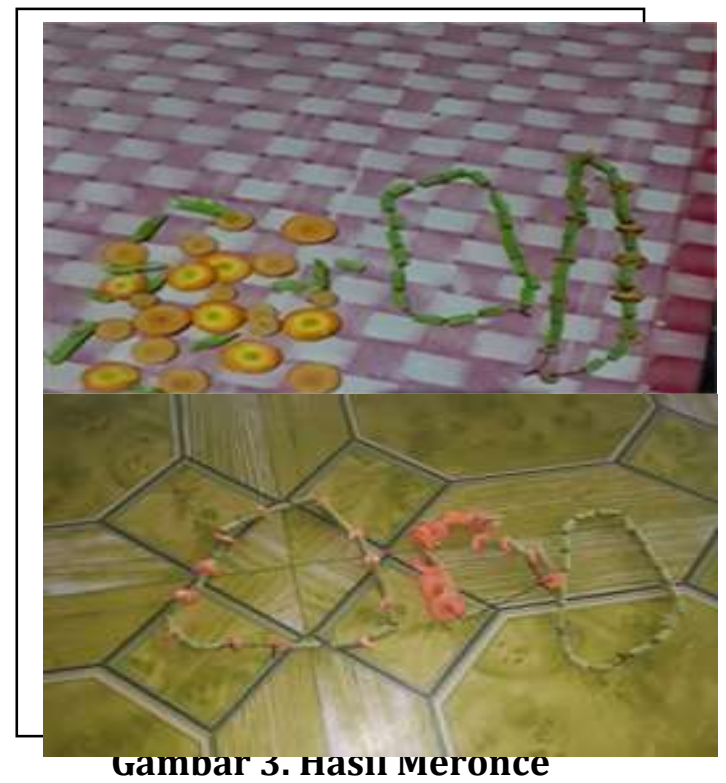




\section{E. KESIMPULAN}

Kegiatan meronce sangat bermanfaat bagi anak, dengan tujuan meningkatkan kreativitas anak, meronce bahan yang digunakan adalah bahan-bahan alam yaitu wortel dan kacang panjang. Dengan kegiatan meronce dapat membantu kemampuan motorik halus, melatih koordinasi mata dan tangan, serta meningkatkan perhatian dan konsentrasi sehingga kegiatan meronce anak akan merasakan dan mendapatkan pengalaman yang baru.

Berdasarkan hasil data yang diperoleh dari penelitian sebelumnya bahwa kemampuan motorik halus anak dapat mengalami perkembangan melalui kegiatan meronce. Hal ini dapat diketahui dari hasil penilaian dimana rata-rata kemampuan motorik halus anak pada mengalami peningkatan. 


\section{DAFTAR PUSTAKA}

Andri Setia Ningsi 2015. Identifikasi Perkembangan Keterampilan Motorik Halus Anak Dalam Berbagai Kegiatan Main Di Kelompok B. Jurnal Pendidikan Guru Pendidikan Anak Usia Dini Edisi 7 Tahun ke-4 2015 (Diakses 10 Mei 2020)

Ari Wulandari 2019. Penerepang Metode Demonstrasi Melalui Kegiatan Meronce Untuk meningkatkan Perkembangan Motorik Halus. Jurnal Ilmia Pendidikan Profesi Guru Vo, 2 No,3 Oktober 2019

Baiti Nur, 2018. Mengembangkan Kemampuan Motorik Halus Melalui Kegiatan Meronce Dengan Bahan Alam Pada Anak Kelompok A Tk Dharma Wanita 03 Padang. Kediri: Skripsi, Universitas PGRI Nusantara (Diakses $8 \mathrm{Mei}$ )

Effi Kulama Sari 2012. Peningkatan Perkembangan Motorik Halus Anak Melalui Kegiatan Kolase Dari Bahan Bekas Di Taman Kanak-Kanak Aisyaiyah Simpang Iv Agama. Jurnal Pesona PAUD Vol.1 No. 1. (Di Akses 6 januari 2020)

Fidah Etrika Nugraha, 2017. Perkembangan Motorik Halus Anak Usia Dini 5-6 Tahun Di Tk Gugu 111 Kecamatan Piyungan Bantul. Yogyakarta: Skripsi, Universitas Negeri (Diakses 8 Mei 2020)

Gusti Ayu Mulyawarni 2019. Melalui Kegiatan Meronce Bentuk Dan Warna Dapat Meningkatkan Kemampuan Motorik Halus Anak Pada Kelompok B Tk Harapan Kelayu. Jurnal Edukasi dan Sains: Volume 1, No1 Agustus 2019

Handayani Tri Rezeki 2016. Keterampilan Meronce Anak Kelompok B TK Gugus 2 Kecamatan Kokap. Yogyakarta: Skripsi, Universitas Negeri (Di Akses 6 januari 2020)

Krisna, Dkk 2018. Meningkatkan Kemampuan kognitif Anak Usia Dini Melalui Kegiatan Meronce Berbentuk Bahan Alam. Jurnal Media Edukasi: Volume 2, Nomor 1, Juni 2018

Mansyur Romadon Putra 2017. Peningkatan Kemampuan Motorik Halus Anak Usia 5-6 Tahun Melalui Kegiatan Menggunting Terbimbing Di Paud Al Fatih. Jurnal AUDI, Volume 2, Nomor 1, hlm $50-55$

Niamul Istiqomah 2018. Pengaru Kegiatan Kolase Dengan Menggunakan Media Bahan Alam Terhadap Keterampilan Motorik Halus Pada Anak Kelompok B Di Raudhatul Athal Perwanida 1 Bandar. Lampung: Skripsi: Universitas Islam Negeri Raden Intan

Reiska Primanisa, Dkk 2020. Tindakan Lanjut Hasil Asesmen Terhadap Pelaksaan Pembelajaran Anak Usia Dini DI Taman Kanak-Kanak. Jurnal Pendidikan Raudatul Athal Volume 3, No 1, Maret 2020 (Di Aksese 15 Mei 2020)

Ropiah 2019. Upaya Meningkatkan Kemampuan Motorik Halus Melalui Kegiatan Meronce Pada Anak Usia 5-6 Tahun Di Tk Pembina 2 Kota Jambi. Jurnal Literasiologi: Volume 2, NO. 1 Januari Juni 2019 
Selia Dwi Kurnia, 2015. Kegiatang Paiting Dan Keterampilan Motorik Halus Terhadap Kreativitas Anak Usia Dini Dalam Seni Lukis. Jurnal Pendidikan Usia Dini Volume 9 Edisi 2, November 2015 (Diakses 15 Mei)

Suriatu, dkk 2020. Meningkatkan Keterampilan Motorik Halus Anak melalui Mencetak dengan Pelepah Pisang. Jurnal Obsesi : Jurnal Pendidikan Anak Usia Dini Volume 4 Issue 1 (2020) Pages 211-223

Tiara Asriandari 2015. Peningkatan Kemampuan Motorik Halus Melalui Kegiatan Meronce Pada Anak Usia 4-5 Tahun Di Tk Negeri Pembina Kayuangung. Sriwijaya: Skripsi, Universitas (Diakses 15 Mei 2020) 